Journal of Economics, Finance and Accounting Studies (JEFAS)

ISSN: 2709-0809

DOI: $10.32996 /$ jefas

Journal Homepage: www.al-kindipublisher.com/index.php/jefas

\title{
Total Factor Productivity Growth of Ghanaian Electricity Distribution Utilities Using Data Envelopment Analysis and Malmquist Index (2000-2020)
}

\author{
Smart Edward AManfo \\ Graduate School of Global Environmental Studies, Sophia University, Tokyo, Japan \\ $\square$ Corresponding Author: Smart Edward Amanfo, E-mail: smart6783@gmail.com
}

\begin{abstract}
ARTICLE INFORMATION
Received: 11 October 2021

Accepted: 26 November 2021

Published: 25 December 2021

DOI: 10.32996/jefas.2021.3.2.23

\section{KEYWORDS}

Ghana, Electricity Distribution Utilities, Electricity Economics, DEA, Malmquist Index, Total Factor Productivity, Growth, Electricity Transmission Losses, Electricity Distribution Utilities, Undesirable output, JEL Classification: D24, L94, K32

\section{ABSTRACT}

The increasing need for electricity access to drive economic growth, social development, poverty alleviation and environmental sustainability requires that efficient allocation of scarce and competing resources in the generation, transmission and distribution subsectors of the electricity sector is indispensable. This paper analyses total factor productivity growth in a single input multiple-output framework in Ghana. The technique applied is data-orientated nonparametric Data Envelopment Analysis using Win4Deap 2 software. Total Factor Productivity Change is evaluated through Malmquist Productivity Index (MPI), as well as technological change (TECHC) and efficiency change (EFFCH) using firm-level panel data. Sources of productivity growth comparison are made between Electricity Company of Ghana (ECG) and the Northern Electricity Distribution Company (NEDCO) for the periods 2000 to 2020. The results show $\mathrm{TECHCH}$ marginally declined at an average annual rate of $0.3 \%$ and drives the electric power distribution productivity regress in ECG and NEDCO from 2000 to 2020. Further, the results indicate stagnation in scale efficiency, pure efficiency and efficiency change when estimated over 20 years. At firm levels comparison, the study shows that the Northern Electricity Distribution Company recorded a productivity growth rate of $4.9 \%$, mainly due to technical progress. However, the Electricity Company of Ghana experienced a slight deterioration of productivity performance due to a $5.3 \%$ decline in technical efficiency. The study offers several policy recommendations on how the underperforming firm can learn to improve efficiency and technical to reduce electricity transmission losses.
\end{abstract}

\section{Introduction}

The electricity economics in any economy can be modelled as electricity demand economics (demand-side management) plus electricity and supply economics (supply-side management) (Hu \& Hu, 2013). To this extent, the electricity market value chains include generation, transmission and distribution of electric power to potential end-users. Whereas the three functions of generating, transmitting and distribution of electric power are historically monopolized by central governments, recent decades have witnessed a growing liberalization and restructuring of state-owned power systems into three independent entities, namely power generation, power transmission, and power distribution (Nagsarkar \& Sukhija, 2014). In the face of the above-growing complexities in the electricity power sector in developing, emerging, and developed economies alike, the empirical scholarships pertaining to electricity production have received wide attention. However, the distribution function of electric power systems, whose inefficiencies may impose serious environmental, social, economic or political costs on society, 'has more or less neglected'(Hjalmarsson \& Veiderpass, 1992). Notwithstanding, the ongoing market liberalization forces, propelling state-owned electricity deregulation and private, public partnership (PPP) have ignited a growing stake in research and development (R\&D), productivity growth, managerial and technical efficiency of the entire electric power subsector.

As the efficient allocation of resources is the mantra of market economy, and for that matter, liberalized electricity markets like Ghana's, one of the ways to exert goal-orientated demands on distribution utilities to operate optimally is to ensure a continuous

Copyright: (c) 2021 the Author(s). This article is an open access article distributed under the terms and conditions of the Creative Commons Attribution (CC-BY) 4.0 license (https://creativecommons.org/licenses/by/4.0/). Published by Al-Kindi Centre for Research and Development, London, United Kingdom. 
evaluation of their efficiency and productivity performance over a period time. This is because the energy sector, in general, is capital intensive (Ragheb, 2017) and sometimes require social overhead costs bored by taxpayers' money. This requires efficient allocation of scarce and competing resource spaces in the energy sector. Such a concern is more crucial in low-income economies with limited and competing fiscal space. For instance, the imposition of the 'Energy Sector Levies' to 'provide funding for power generation and the clearance of legacy debts accumulated within the sector' (Report on the Management of the Energy Sector Levies and Accounts, 2020) accounts, in part for the high cost of electricity and other energy commodities. The energy sector legacy debt of Ghana is largely due to inefficiencies in the value chains of electricity supply and corruption. In addition, a perspective of energy generation-ecological systems health nexus reveals that electricity generation is a major contributor to anthropogenic greenhouse gas (GHG) emissions. In particular, about $70 \%$ of the total GHG emissions emanated from electricity generation, transmission and distribution (Koch, 2020). In this context, Biggar and Hesamzadeh (2014) proposed higher efficiency use of generations, the network and demand-side resources, as well receptive to the very short-run disequilibrium in demand and supply of power as a short-term task of the electricity industry. Therefore, it is prudent if efficiency and productivity, which theoretically implies minimizing input factors without reducing output, or increasing output with the same level of input factors (Prasetyo \& Zuhdi, 2013), becomes a guiding principle for electricity generation, transmission and distribution entities, especially in low-income economies. Giving multiple-input and output, data-oriented and technology characteristics, the appropriate technique for efficiency and productivity evaluation of electricity distribution utilities should be considered. Simple ex-ante and ex-post ante performance evaluation indicators are inadequate, giving constant regulation and technology dynamics in the electricity sector. Total factor productivity change, which informs the performance of decision-making units, overtime is required.

This study focuses on two main objectives. Firstly, to evaluate total factor productivity (TFP) growth, and secondly, to describe the sources of productivity growth in the national distribution of electric power in Ghana for the period 2000 and 2020. Two electricity retail (utilities) companies: The Electricity Company of Ghana (ECG) and the Northern Electricity Distribution Company (NEDCO), are considered as decision-making units used in the study. A firm-level panel data was constructed for ECG \& NEDCO. Giving the availability of firm-level panel data, the Malmquist Productivity Indices (MPI) are computed employing a nonparametric data envelopment analysis (DEA) technique.

In both production economics and growth accounting, the output of firms can be quantified in various ways. In this paper, two outputs and single input are considered in the model. Data on the outputs and input were derived from the National Energy Statistics provided by the Energy Commission of Ghana and Ghana Open Data Initiative databases. The data on 'Power Purchase' is considered as an input. Whereas there is no definition for 'Power Purchase' from the data source, it can simply be quantified as the amount of electric power sold and bought by distribution utilities, while 'Power sales' is the quantity of power purchased and sold to the end-users, which include residential, service, transport and transport subsectors of electricity consumption (National Energy Statistics, 2021, p. 30). Whereas the Energy Commission of Ghana only declared electricity distribution losses as constituting both 'technical and commercial losses'(National Energy Statistics, 2021), Cretì and Fontini (2019) have provided a useful computational definition from an electricity economics perspective which conceptualized electricity transmission losses as the differences between power production and consumption. The study modelled the percentage power losses,' therefore defined here as total power sales (in GWh) as a percentage of the total power purchase (in GWh) in a period of time an output variable.

The modelling of the above variable as an output in the DEA model is based on extensive DEA theoretical and empirical literature review (Halkos \& Petrou, 2019; Wang, Hsu, Wang et al., 2020), for example. For instance, some researchers using DEA for efficiency and productivity modelling argue that for a number of production processes, the generation of 'undesirable outputs' or 'bad outputs' in the form of by-products is inevitable (Eyni, Tohidi, \& Mehrabeian, 2017; Kao \& Hwang, 2021; "Undesirable Outputs Models," 2007; Yang \& Pollitt, 2009; Zhao, Zeng, Li et al., 2022; Peng Zhou, Poh, \& Ang, 2016). In the electricity sector, grid-based GHG emissions constitute non-discretionary and undesirable outputs. Researchers in the banking sector have also quantified nonperforming loans and assets as undesirable outputs (or bad) (Dar, Mathur, \& Mishra, 2021). The rising interest among the DEA scholars to incorporate undesirable outputs or by-products in analyzing the efficiency of entities is attributed largely to the growing concerns about social metabolism in terms of energy and material use and existential negative effects on the health of socialecological systems (Sueyoshi \& Goto, 2018).

However, maximizing an undesirable output is inconsistent with the theory of DEA. The key assumption of DEA theory is that efficient DUM(s) should minimize inputs of production while maximizing outputs (Hua \& Bian, 2007). In the case of this study, it is inconsistent with the DEA to aim at maximizing the 'percentage of power transmission losses', as that could not be an objective function of the distribution utilities under consideration. However, undesirable outputs (power losses in the context of this paper) are jointly produced with desirable outputs (Fare, Grosskopf, \& Margaritis, 2015); ( electricity sales in GWh in this paper). Leaving an undesirable output out of models assessing the electricity sector performance can produce a less robust result for policy 
modelling. Following the literature, three approaches have been proposed to deal with the challenges of the existence of 'bad outputs' in the production activities; of course, researchers differ with this remediation.

\section{Literature Review}

This section briefly reviews relevant literature on the concept and measurements of total factor productivity and irregular input/output data, such as the incorporation of undesirable outputs (bad outputs) and Ghana's electricity distribution utility issues.

\subsection{Total Factor Productivity Growth Measurements}

Productivity $(P)$ simply refers to the number of goods and services that can be produced per unit of factor input employed in a period of time (Mankiw, 2020, p. 546). It is a measure of the ratio of output produced (Y) in time $t$ to factor input employed in time $t$, that is $P_{t}=\frac{Y_{t}}{X_{t}}$. Total factor productivity (TFP) is defined as the ratio of total output produced to total factor inputs employed in a period of time. In the growth accounting literature, the concept of TFP is applied as an index that represents a source of growth among entities or economies that is not explained by factor inputs employed. TFP index is a relative comparison of outputs produced across time or between different units of production. For instance, where it is economically feasible to increase total output in period $t+1$ when employing the same units as input production in period $t$, then it is conclusive that a hypothetical firm has achieved improvement in productivity (productivity growth). Stated differently, productivity is improved in the present period

in comparison to the preceding period $P_{t+1}>P_{t}$. Where all factor inputs employed in the production processes are quantified, then theoretically, TFP growth can be conceptualized as that part of the growth in real total outputs that is not explained by inputs employed. Abramovitz (1956) conceptualized the TFP as a 'measure of our ignorance within this logic. In the same line of reasoning, Robert Solow (1957), as cited in Peat and Hartwick (2015), describes part of the growth that is not accounted for by growth in input factors as the 'Solow Residual', which can be estimated from the classical Cobb-Douglass production function (Matilde Mas, 2020). Given that the levels of TFP are known to be sensitive to measurement units of input factors and output, TFP itself is not of practical interest to researchers. However, the quantification of TFP growth is of both policy and empirical interest. Therefore, it is common in the literature to apply the notion of 'TFP' to represent growth/improvement as against levels. The study, therefore, adopts this conventional measurement and notation.

\subsection{Dealing with undesirable outputs in DEA-Malmquist Model}

As mentioned in the introductory section, production activities often than not result in an 'object-and-shadow' scenario whereby it becomes practically impossible to produce a desirable output (input) without simultaneously producing 'undesirable outputs (inputs)' or 'bad outputs (inputs) (Zhu, 2014). The daunting challenge in both theory and empirics is to deal with inputs or outputs data that are inconsistent with DEA assumptions, and also, manager's point of view of accepting the results of irregular data DEA models. Thus, in their book titled: Data Irregularities and Structural Complexities in DEA, Zhu and Wade (2007) remarked the need to incorporate such irregular outputs/inputs in organizations efficiency modelling (Zhu \& Wade, 2007). Whereas there is no agreement among scholars in dealing with undesirable outputs/inputs, there is an agreement that undesirable outputs/inputs should be minimized (much as inputs such as labour and capital) and consequently increase desirable outputs (Halkos \& Petrou, 2019). Whereas scholars are in agreement with the methods of dealing with irregular data DEA modes, the following four main options have been suggested in the literature in dealing with the presence of undesirable outputs, as suggested in (Halkos \& Petrou, 2019).

The crude method: This is the simplest method, involving ignoring the undesirable outputs from the production technology. This means that the undesirable outputs have no value in the final performance evaluation (Halkos \& Petrou, 2019). Whereas this approach is much more convenient, it has a high chance of producing a misleading performance analysis of organizations (Yang \& Pollitt, 2009). In particular, ecological systems undesirable outputs are close to impossible to be separated from the linked desirable output(s), and a cutdown in a bad output also leads to a cutdown in the desirable outputs of firms or an increase in firms' marginal costs due to research and development $(R \& D)$ that brings innovations and efficiency. For instance, in the context of this study, electricity distribution losses (undesirable outputs) are incurred once power transmission took. Ignoring electricity losses in evaluating the productivity performance analysis may mask important information for policymakers and stakeholders for future planning. Few studies (Gomes \& Lins, 2008; Oude Lansink \& Bezlepkin, 2003; Reinhard, Knox Lovell, \& Thijssen, 2000) ignored bad output from their analyses and made detailed comparisons of empirical findings.

Modelling undesirable outputs as inputs: Another method is to model the undesirable variable as an input of production. This option is rooted in the logic that firms optimizing behaviour involves minimizing inputs while maximizing output in production (Rasmussen, 2013b). Scholars following this school of thought have treated undesirable outputs as direct inputs in disciplines such as banking (Fukuyama \& Weber, 2008) and environmental efficiency (De Koeijer, Wossink, Struik et al., 2002; Farzipoor Saen, 2010; Reinhard et al., 2000). 
Modelling the undesirable outputs in the non-linear model: Another option is implying model the undesirable production outputs as regular outputs in the production technology. Researchers, e.g.; (Alfredsson, Månsson, \& Vikström, 2016; Chen, Yu, Chang et al., 2015; Lee, Wilson, Pasurka et al., 2017; Pittman, 1981) have used a direct approach from which both desirable, and 'bad outputs' are modelled in their regular standard. The underlying argument is that firms' desirable outputs may be strongly disposable, whereas the 'bad outputs' are considered possessing disposability weakly (Hua \& Bian, 2007) as their values cannot be changed without altering probably quality and values of other outputs with desirable characteristics (Färe, Grosskopf, \& Roos, 1998).

Models involving transformations in undesirable outputs: This option of dealing with an undesirable output involves applying some transformation to the original undesirable output(s) data. The approach, therefore, assumed a linear monotone decreasing transformations as applied to undesirable outputs (Hua \& Bian, 2007). Undesirable outputs in the forms of greenhouse gas emissions (Park \& Lee, 2012; Seyedalizadeh Ganji \& Rassafi, 2019; Sueyoshi \& Goto, 2011, 2018; P. Zhou, Ang, \& Wang, 2012), emanating from our industrialized-based social metabolism negatively impact the social-ecological systems and should be reduced. This is much crucial in the energy sector, known for its notoriety in anthropogenic greenhouse gas emissions responsible for climate change and global warming (Sueyoshi \& Goto, 2018). As a result, a number of transformations techniques have been applied to undesirable outputs as follows:

(i) $f(U)=-U$; this approach is known as the ADD method and was proposed by (Koopmans 1951). Koopmans' transformation's basic assumption is that the undesirable inputs/outputs will become desirable. However, the data may become less than zero (negative), making a straightforward definition and interpretation scores difficult.

(ii) $f(U)=-U+\beta$; is another translation approach. The logic here is to multiply the undesirable input/output data by negative one $(U \times-1)$ and add the result to a large number $(\beta)$ till a positive result is obtained. Therefore, the desired result is contingent on the value assigned to $\beta$.

(iii) Another method of transforming the undesirable proposed by Golany and Roll (1989) is the multiplicative inverse (MI). That is $f(U)=\frac{1}{U}$, this represents a non-linear transformation. The inverse-transformed data can be used in the DEA model as regular output data. The hyperbolic nature of the MI model means that an efficient firm maximizes $\frac{1}{U}$ and consequently minimizes undesirable outputs, and the net effect will be an improvement in efficiency. This transformation of bad outputs into desirable outputs is widely applied in various DEA studies (Angulo-Meza, González-Araya, Iriarte et al., 2019; Seyedalizadeh Ganji \& Rassafi, 2019; Wang et al., 2020). Following the literature, this study employed the multiplicative inverse transformation to the percentage of electricity transmission losses (undesirable output) as a desirable output based on panel data from the Electricity Company of Ghana and Northern Electricity Distribution Company Limited for the periods 2000 to 2020. The choice of the method is based on comprehensive theoretical and empirical literature (Färe \& Grosskopf, 2004; Seyedalizadeh Ganji \& Rassafi, 2019; Yu, 2004) and modified for this study.

\subsection{Total Factor Productivity Growth Measurement Approaches}

In analyzing productivity growth, it is very important to give credit to the earliest brains whose theoretical and empirical works laid grounds for modern studies of the same. In this context, Solow (1957), an American economist, conceptualized the aggregate production technology and growth accounting model, which shows constant returns to scale (CRS) continues to be extant literature. Later in the 1950s, Solow proposed the concept of total factor productivity (TFP), arguing that technical progress is the key determinant. In spite of Solow's menopausal explanation of the source of TFP growth, his idea provided a concrete theoretical background for further research on total factor productivity growth, especially in modern growth accounting literature (Garzarelli \& Limam, 2019; Sequeira \& Morão, 2020; Shen, Yue, Sun et al., 2020; Timmer \& Ye, 2020). Thijs ten (2019) argues that productivity growth, as estimated by the Solow Residual, and efficiency (catch-up) as measured via the Debreu-Diewer coefficient of input utilization 'can be interrelated' (Thijs ten, 2019, p. 90)

In general, there are two main approaches to quantifying total factor productivity growth across various disciplines, namely frontier and non-frontier approaches. A common approach in the literature of the non-frontier technique, which does not accommodate technical regress (technical inefficiency), but contests the main source of growth in TPF is technical progress. The non-frontier 
techniques can be further portioned into two: the parametric or deterministic methods, which basically applies the average function techniques. The second - nonparametric methods, for instance, exponential-function based methods (Carter, Chen, \& Chu, 2003; McMillan, Whalley, \& Zhu, 1989), and also growth accounting methods (Fan, 1991; Lin, 1992). Scholarships on the exploration of TPF growth mainly began with the frontier methods. Some researchers argue that it was since the frontier model received empirical attention in the middle of the 1990s (Wan \& Zhou, 2021). Unlike the non-frontier methods (Wan \& Zhou, 2021), the frontier models provide model adequacy as they consider the role of technical efficiency. Among the frontier models, the literature offers the parametric techniques; which includes stochastic frontier analysis (SFA) (Timothy J Coelli, Rao, O'Donnell et al., 2005; Gupta, Badal, \& Phytochemistry, 2021; Kumbhakar \& Lovell, 2003), deterministic frontier analysis (DFA) (Afriat, 1972). The nonparametric version of the frontier models includes and is usually based on the MPI (Malmquist Productivity Index), which is mainly based on the DEA methodology (Tim J Coelli \& Rao, 2005; Guo, Deng, Wang et al., 2021). In terms of relative advantage, the DEA appears to be superior. In that, decomposition of TFP index is possible, it does not require any prior model assumptions of production technology (Kumbhakar \& Lovell, 2003), compared to the classical deterministic production function, no parametric model estimation, and accommodates inefficiencies (Färe, Grosskopf, \& Russell, 1997; Orea, Álvarez-Ayuso, \& Servén, 2020).

In Ghana, a few scholars applying the DEA-based MPI in analyzing TFP growth focused their efforts on the agricultural sector (Aidoo, Boateng, Freeman et al., 2021; Hirotaka, Samuel, Victor et al., 2014), manufacturing sector (Ackah, Aryeetey, \& Morrissey, 2012), and cross-country panel productivity analyses (Abekah-Koomson, Loon, Premaratne et al., 2021; Asamoah, Mensah, \& Bondzie, 2019; Dzeha, Turkson, Agbloyor et al., 2018; Meniago \& Lartey, 2021). Based on limited information from the literature reviewed, there are no research efforts in Ghana's context that investigates productivity growth in the electricity sub-sector; in spite of the fact that the sub-sector remains one of the key preconditions of the country's long-term development goal of socialeconomic and structural transformation as indicated in the Forty-Year-Development-Plan². For instance, Gaggl, Gray, Marinescu et al. (2021) opine that 'Electricity was the catalyst for the second industrial revolution in the early twentieth century'. This suggests the extent to which electricity could be considered a critical infrastructure network system for which power generation, transmission and distribution value chains must ensure higher managerial and technical efficiency that propel productivity to drive social and economic transformation in the country, all things being equal. Therefore, this paper aims to estimate productivity growth in retail electricity distribution and describe the sources of productivity by decomposing the TFPCH using a DEA-MPI capability in Win4Deap 2 programme.

The Malmquist productivity index has a number of attractive features, which makes it amendable to assess the productivity performance of Ghana's electricity retail utility sector. Firstly, unlike the parametric methods, which use a predetermined production function assumption and could hardly handle multiple outputs, the DEA can accommodate multiple outputs. This feature is specifically crucial for the electric utility sector characterized by heterogeneous inputs and outputs, complex supply value chains, and sometimes a lack of price information in low-income economies like Ghana. Secondly, with the ongoing deregulation of the electricity sub-sector of Ghana's energy sector, measuring efficiency and productivity performance among competing retail distribution utilities will provide information for firms to learn from best practices. For example, electricity distribution, including technical and commercial losses, continues to be high among the two main distribution utilities in Ghana (ECG and NEDCO) considered in this study. Finally, the DEA-MPI can be decomposed into efficiency change (hereafter EFFCH), technical efficiency change (hereafter TECHCH), pure efficiency change (hereafter PECH), and scale efficiency change (hereafter SECH). Firms' performances relative to the various components of MPI can inform policymakers whether to focus on managerial efficiency or technological efficiency in order to drive productivity or eliminate resources wastage where necessary.

Following the work of Glass, Kenjegalieva, Sickles et al. (2019) and modified for this study, the notation $C^{\phi t+1, t}$ is used to represent the input-oriented estimation of radial efficiency, following the constant returns to scale assumptions proposed by Charnes, Cooper and Rhodes (hereafter, the CCR model) for a representative, retail electricity distribution utility in Ghana observed in time $t$, giving the existing technology in time $t+1$. Again, it $V^{\varphi t+1, t}$ is used for the same logic as above but represents variable returns to scale (VRS) assumption as proposed by Banker, Charnes and Cooper (thus, the BCC model) (Banker, Charnes, \& Cooper, 1984). Given the availability of time series data for the firms studied $E F F C H$ can further be decomposed to allow for useful information on the contribution of scale efficiency change $\mathrm{SECH}$ estimated from the CRS assumption.

\footnotetext{
${ }^{2}$ Ghana's Forty-Year-Development-Plan has the following four sectors:

1. Social Development,

2. Economic Development,

3. Environmental Development and,

4. Institutional Development and Governance. See https://ndpc.gov.gh/developments/social development.
} 
For the purpose of this study, SECH estimates productivity growth due to a scale change that brings a power distribution utility to, or a distance away from the optimal scale of power sales and reduction in transmission losses (the two outputs considered in this study) as indicated by a VRS technology (Fare, Grosskopf, \& Lovell, 1993). Following the literature, the scale efficiency can be measured by the ratio of the Farrell radial version of efficiency computed under the CRS to the Farrell radial efficiency computed under the VRS assumption. Therefore, given two data points: period $t$ and period $t+1$, four scale efficiency measurements are feasible; accordingly: scale efficiency for the data point in time $t$ with respect to the period $t$ production technology; scale efficiency for the data point $t$ with respect to the period $t+1$ production technology; scale efficiency for the data point $t+1$ with respect to the period $t+1$ production technology, and scale efficiency for the data point $t+1$ with respect to the period $t$ production period as expressed in the equations below:

$$
\begin{aligned}
& \sigma^{t}\left(X_{0}^{t}, Y_{0}^{t}\right)=\frac{C^{\phi t, t}}{V^{\phi t, t}} \sigma^{t+1}\left(X_{0}^{t}, Y_{0}^{t}\right)=\frac{C^{\phi t+1, t}}{V^{\phi t+1, t}} \sigma^{t+1}\left(X_{0}^{t+1}, Y_{0}^{t+1}\right) \\
& =\frac{C^{\phi t+1,1}}{V^{\phi t+1,1}} \sigma^{t}\left(X_{0}^{t+1}, Y_{0}^{t+1}\right)=\frac{C^{\phi t+1, t}}{V^{\phi t+1, t}}
\end{aligned}
$$

Where $\sigma$ is the measure of input and output distance input functions?

And Equation (1) can be broken down into SECH as follows:

$$
S E C H=\left[\frac{\sigma^{t}\left(X_{0}^{t+1}, Y_{0}^{t+1}\right)}{\sigma^{t}\left(X_{0}^{t}, Y_{0}^{t}\right)} \frac{\sigma^{t+1}\left(X_{0}^{t+1}, Y_{0}^{t+1}\right)}{\sigma^{t+1}\left(X_{0}^{t}, Y_{0}^{t}\right)}\right]^{\frac{1}{2}} \ldots \ldots \ldots \ldots \ldots \ldots \ldots \text { (2). }
$$

Furthermore, we parametrized CRS and VRS Malmquist productivity index as $M P I_{C R S}$ and $M P I_{V R S}$ respectively as follows:

$$
M P I_{C R S}=\left(X_{0}^{t}, Y_{0}^{t}, X_{0}^{t+1}, Y_{0}^{t+1}\right)=\left[\frac{C^{\phi t+1,1}}{C^{\phi t, t}}\right]\left[\frac{C^{\phi t, t}}{C^{\phi t+1, t}} \frac{C^{\phi t, t+1}}{C^{\phi t+1, t+1}}\right]^{\frac{1}{2}}
$$

And VRS version of MPI change version as:

$$
M P I_{V R S}=\left(X_{0}^{t}, Y_{0}^{t}, X_{0}^{t+1}, Y_{0}^{t+1}\right)=\left[\frac{V^{\phi t+1, t+1}}{V^{\phi t, t}}\right]\left[\frac{V^{\phi t, t}}{V^{\phi t+1, t}} \frac{V^{\phi t, t+1}}{V^{\phi t+1, t+1}}\right]^{\frac{1}{2}}
$$

Each of the MIP indexes can be broken down as a measure of EFFCH, which is represented by the first expression (ratio) in the first square brackets, and technical change (frontier shift) denoted by the expression in the second brackets. Following (Sharif, Gunardi, Hasan et al., 2019) and modified, we finally modelled the relationship between the decomposed indices as follows:

$$
M P I_{C R S}=\left(X_{0}^{t}, Y_{0}^{t}, X_{0}^{t+1}, Y_{0}^{t+1}\right)=M P I_{V R S}\left(X_{0}^{t}, Y_{0}^{t}, X_{0}^{t+1}, Y_{0}^{t+1}\right) \times S E C H
$$

Based on Equation (5), we can completely decompose the DEA-MPI TFP change into the three main components to determine the sources of productivity growth in ECG and NEDCO for the period 2000-2020 as follows:

$$
\triangle M P I=\triangle E F C H \times \triangle T E C H C H \times \triangle S E F
$$

where $\triangle$ denotes change, $E F F C H=$ efficiency, $T E C H C H=$ technical efficiency, and $S E C H=$ scale efficiency.

The resulting $M P I=1$ implies TFP stagnation (no productivity growth, neither productivity decline), $M P I>1 \rightarrow$ improvement in TFP between period $t$ and $t+1$. 
$M P I<1$ Conveys evidence of TFP decline (TFP regression) between period $t$ and $t+1$. These interpretations have been applied in various DEA-Malmquist TFP growth studies in agriculture, e.g.; (lliyasu, Mohamed, \& Hashim, 2015; Kataoka, 2020; Mombini, Rostamy-Malkhalifeh, Saraj et al., 2020).

DEA is adaptable to firm-level panel data by computing the DEA-Malmquist productivity index. The total factor productivity changes over a period of time can result from three main sources (R. Färe \& Grosskopf, 1998; Fare, Grosskopf, \& Lovell, 1994). Firstly, an entity's technical efficiency may change, given the entity's scale of operations. Secondly, the efficiency (catching up) of a decision-making unit can change as a result of a change in the firm's level of operations scale (Ray, 2019). Thirdly, the prevailing production technology may change over time, thus exerting an inward or outward effect on the production frontier, which may have an aggregate effect on the efficiency performance of entities. The malmquist productivity index provides flexibility to compute each of these changes by computing distinct distance functions for each production period by altering the assumptions (CRS or VRS) about the prevailing production technology. Therefore, the DEA-Malmquist productivity index is a measurement of the decision-making units overall total factor productivity change (Thanassouli, 2001). The dual linear programming (LP) for an outputorientated DEA under the VRS assumption, proposed by Banker, Charnes, and Cooper (1984) (hereby abbreviated as the BCC) model, can be derived the following.

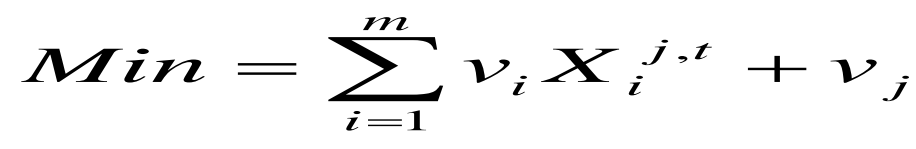

Subject to:

$\sum_{r=1}^{s} u_{r} Y_{r}^{j, t+1}=1$

Given the required LP to estimate both input and output distance functions, it is assumed in the study that:

$i=$ individual type of factor input (electricity power purchase) $(\mathrm{i}=1=\mathrm{M}=$ electricity power purchase)

$j=$ the given power utility distribution under consideration from the sample $(\mathrm{j}=1,2, \ldots, \mathrm{J})$

$v_{j}=$ the weight assigned to activity of power distribution utility $\mathrm{j}$

$\mathrm{t}=$ time period $(\mathrm{t}=1,2, \ldots, \mathrm{T}=2000,2001 \ldots, 2020)$

$\mathbf{J}=$ number of decision-making units in the sample $(\mathrm{j}=1,2=\mathrm{J}=\mathrm{ECG}, \mathrm{NEDCO})$

$v_{i}=$ activity weight assigned to input factor $\mathrm{i}$

$u_{r}=$ activity weight assigned to the output type $\mathrm{r}$

$\mathrm{r}=$ category of output in the sample $(\mathrm{r}=1,2=\mathrm{S}=$ electricity power sales $(\mathrm{GWh})$ and the invese of $\%$ of electricity transmission losses)

$X_{i}^{j, t}=$ amount of the $\mathrm{i}$-th input factor (electricity power purchase $(\mathrm{GWh})$ ) sold by the $\mathrm{j}$-th distribution utility in time $\mathrm{t}$

$X_{i}^{j, t}=$ amount of the $\mathrm{i}$-th input (electricity power purchase) and sold by $\mathrm{j}$-th utility distribution utility in period $\mathrm{t}$

$Y_{r}^{j, t}=$ amount of the r-th ouput (electricity power and the inverse of $\%$ of power transmission losses

by the $\mathrm{j}$-th distribution utility in period $\mathrm{t}$ )

$\mathrm{Y}_{m}^{j, t}=$ amount of the $\mathrm{r}$-th output (electricity power and the inverse of $\%$ of power transmission losses)

by the $\mathrm{j}$-th distribution utility in period $\mathrm{t}$

The classical DEA model (CCR) (Charnes, Cooper, \& Rhodes, 1978) is based on the constant returns to scale assumptions, implying that any variation in factor inputs should result in a proportional increase (decrease) in output (Rasmussen, 2013a, 2013c). However, this assumption is only tenable in the sector with high market economy characteristics. The energy sector, with its existential linked to national security, especially the electricity subsectors, is highly regulated with obvious natural monopolies (Mydland \& Lien, 2020), notwithstanding ongoing regulations. As a result, the CRS assumption may not always hold. Following argument reputed 
by Banker, Charnes and Cooper (the BCC model), which improves upon the CCR model by adding that, at varying scales, the decision-making units (ECG and NEDCO, for the study) can exhibit productivity and yet be noted efficient. Therefore, the BCC model aims to incorporate the notion that under varying situations, the factors that drive the productivity of production processes are likewise diverse. Ghana's electricity sector exhibits more probable characteristics amendable to the BCC model as compared to the CCR model. Thus, the DEA-Malmquist productivity index is estimated using the output-orientated and VRS assumptions built in the Win4Deap 2 software. Similar methodology and line of argument have been applied in (Mydland \& Lien, 2020).

\subsection{Evolution of Ghana Retail Electricity Distribution Utilities-Brief}

This subsection briefly reviews Ghana's electricity system in terms of the three major actors. Ghana's electricity sector has three main sub-sectors: the power generation companies (producers), transmission companies (transmitters) and distribution companies (distribution utilities) (Figure 1). However, this study focuses on the performance evaluation of the distribution subsector, officially 'Distribution Utilities' (National Energy Statistics (NES) Ghana, 2021, p. 29).

Table 1 : Distribution Utilities' Purchases, Sales and Losses (GWh) (2000-2020)

Source: Author's own compilation using data from (National Energy Statistics (NES) Ghana, 2021).

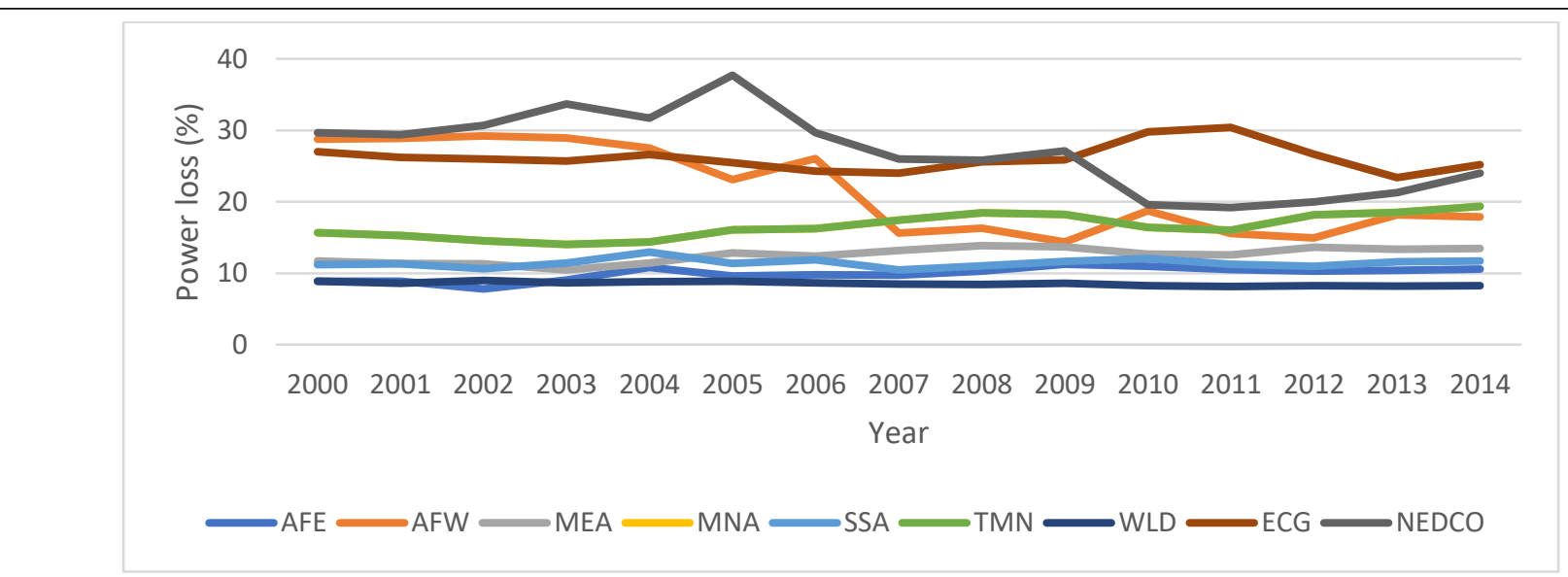

Figure 1: Electricity power losses (\%) between ECG, NEDCO and other regions (2000-2014)

Source: Author's own compilation using data from (National Energy Statistics (NES) Ghana, 2021) and World Development Indicators (https://data.worldbank.org/indicator/EG.ELC.LOSS.ZS).

Note: AFE = Africa Eastern and Southern. AFW = Africa Western and Central. MNA = Middle East \& North. Africa, SSA $=$ subSaharan Africa. TMN = Middle East \& North Africa (IDA \& IBRD countries). WLD = World, ECG = Electricity Company of Ghana. NEDCO $=$ Northern Electricity Distribution Company.

Following the various reforms, especially deregulation of the electricity sector, there are currently three electricity power Distribution Utilities: Electricity Company of Ghana (ECG), the Northern Electricity Distribution Company Limited (NEDCO) and Power Enclave Company (PEC). The NEDCO is legally mandated to distribute power to Ahafo, Brong-Ahafo, Bono East, Savannah, Northern, North-East, Upper East, and Upper West and some parts of Ashanti, Western North and Oti Regions of Ghana, and therefore, occupies about $64 \%$ of the geographical region of Ghana (Sustainability Report, 2020). On the other hand, the ECG is responsible for power distribution in the southern and middle parts of Ghana (Ibid.). PEC only acquired a license as a power distribution entity in 2015. From the energy sector regulation laws in Ghana, the main activities of the Distribution Utilities are power purchases and sales, as indicated in the Energy Commission of Ghana's National Energy Statistics. In 2020, a total of 14,524 GWh compared to $10,7178 \mathrm{GWh}$ by Distribution Utilities in Ghana, representing 3,807 GWh. In terms of performance of individual Utilities Distribution companies, ECG, NEDCO and PEC, respectively, recorded an annual compound growth rate of $6 \%, 8 \%$ and $16 \%$ between 2000 and 2020. The total power sales increased from 5,831 GWh, $719 \mathrm{GWh}$ and $96 \mathrm{GWh}$ in 2015 to 9,333 GWh, 1,148 GWh and 237 GWh for ECG, NEDCO and PEC respectively in 2020. 
Currently, ECG remains the largest power buyer, accounting for about $87 \%$ of total power purchases (see Table 1), whereas NEDCO and EPC, respectively, accounted for $11 \%$ and $2 \%$ of the total power purchases, respectively. In terms of electricity transmission and distribution losses, ECG, NEDCO and PEC, respectively, accounted for 3,314 GWh (88\%), 428 GWh (11.3\%) and 5 GWh $(0.1 \%)$ in 2020. However, for lack of enough data points for PEC, the study only considered ECG and NEDCO for the analysis of total factor productivity growth from 2000 to 2020. PEC could be included in a future study as comprehensive time-series data becomes available. From Table 1, it appears electricity transmission losses, also known as 'line losses' (Wu \& Ni, 2015), both in nominal and percentage terms, are increasing function of power purchases and sales among Distribution Utilities in Ghana.

Figure 1 illustrates electricity transmission losses of the Electricity Company of Ghana, Northern Electricity Distribution Company, and the rest of the world. Evidentially, the power transmission losses among the two main power distributors in Ghana are far above the world and sub-Saharan African region (including other regions) averages from 2000 to 2014, where data is available for comparative analysis. Whereas these losses are reputed as purely an engineering problem, their social, economic and ecological consequences are overwhelming. For instance, empirical studies have confirmed the negative relationship between electricity transmission losses and economic growth in Ghana (Samuel, Edem Kwame Mensah, \& Richmond Odartey, 2017) and South Africa (Adams, Atsu, Klobodu et al., 2020). From the perspective of electricity economics, line losses are crucial components of assessing the extent of efficiency, resilience and sustainability of the power infrastructure network systems. Electricity transmission losses quantify the quantity of generated electricity that enters energy carriers versus the useful quantity transmitted to the rightful endusers (Jiménez, Serebrisky, \& Mercado, 2014).

Thus, in accessing the productivity performance of electricity utilities, ignoring electricity transmission losses, conceptualized in the study as 'undesirable outputs' using DEA theory is likely to mask important information needed by various stakeholders in the sector.

\section{Data and Methods}

This section presents the methods and data variables used in the study. In estimating a DEA-Malmquist total factor productivity growth, one of the key challenges is how to select the appropriate inputs and outputs (Wojcik, Dyckhoff, \& Clermont, 2019). This is because the choice of inputs and outputs variable data may have a significant effect on the efficiency scores and distribution of the same. Moreover, in spite of being developed on the bedrock of production economics (Charnes, Cooper, Golany et al., 1985; Fare, Grosskopf, \& Lovell, 1994), considerable research involving it's (DEA) applications fall outside the domain of real production activities (Wojcik et al., 2019). This situation imposes crucial challenges in DEA-based efficiency and productivity estimations. For instance, the concern pertaining to how to choose and operationalize production inputs and outputs are essential for the performance evaluation at hand (Wojcik et al., 2019). Relating to this specific important general concern, Cook, Tone, and Zhu (2014), in their discussions on 'DEA: Prior to choosing a model' states: ' ..., if the underlying DEA problem represents a form of "production process", then "inputs" and "outputs" can often be more clearly identified. The resources used or required are us ually the inputs, and the outcomes are the outputs.'

However, since the theoretical and practical wisdom of DEA measurement is 'benchmarking', then the traditional firm optimization behaviour theory suggests that rational decision-making units will, on average, consider 'the-less-the-better' for inputs and 'themore-the-better' for desirable outputs, as argued by Wojcik et al. (2019). Based on the above review, one question was invoked as a guide in choosing the input and outputs for the study, which is 'What will ECG and NEDCCO as entities want to maximize or minimize'? Using this question, efforts were made to choose as possible a comprehensive input and outputs which resonate well with electricity distribution retail utility activities to provide a robust and informative estimation outcome, given the availability of a fairly long firm-level time series data. The available data points were employed to construct one input and outputs. The inputs constructed include the annual power purchases in GWh. The output variables, however, comprise what is known in DEA theory as desirable output, which is the annual electricity power sales in GWh, and it constitutes regular data. The other output, annual power losses as a percentage of total electricity sales. This data is rather irregular data as losses constitute undesirable outputs for both ECG and NEDCO. The percentage of electricity transmission losses was converted into desirable output following theoretical and empirical DEA literature.

\section{Results and Discussion}

This section shows the empirical results of the paper.

\subsection{Temporal Changes of Electricity Retail Utilities Distribution and Its TFP Decomposition in Ghana}

Win4Deap 2 programme ${ }^{3}$ It was utilized to quantify DEA-MPI and its decomposition into efficiency change (EFFCH), technical change (TECHCH), pure efficiency change (PECH), and ultimately, TFP change e for ECG and NEDCO from 2000 to 2020. In using the MPI to estimate the variations in productivity over the period, the year 2000 has been chosen as the technology base year. The

\footnotetext{
${ }^{3}$ The Win4DEAP 2 programme and user guide are available from the authors at http://www.sigmdel.ca/aed-dea/Win4Deap2lnstall-2-1-0-1.exe.
} 
reader will recall that the $\mathrm{MPI}$ is the geometric mean. Again, instead of the individual results for each of the electricity distribution utilities and years in the study, the researcher rather provided a summary description of the mean performance of the two retail utilities over the twenty-year period, i.e., the Malmquist total factor productivity index. Given that the MPI is multiplicative (Arocena, Saal, Urakami et al., 2020; Bod’a \& Považanová, 2020), its computed means are also multiplicative, or geometric means.

Table 1: Descriptive statistics of the input and output variables (2000-2020).

\begin{tabular}{llll}
\hline Statistic & $\begin{array}{l}\text { Power } \\
\text { Purchases } \\
\text { (in GWh) }\end{array}$ & $\begin{array}{l}\text { Power } \\
\text { Sales } \\
\text { GWh) }\end{array}$ & $\begin{array}{l}\text { Distribution losses } \\
\text { (\% of total power sales) }\end{array}$ \\
\hline Mean & 550,003 & 483,437 & 26,100 \\
Median & 8,898 & 120,343 & 26,631 \\
Maximum & $12,706.000$ & $9,333,000$ & 37,700 \\
Minimum & 1,013 & 1.0100 & 19,200 \\
Std. Deviation & $1,955,799$ & $1,435,862$ & 3,829 \\
Observations & 42 & 42 & 42 \\
\hline
\end{tabular}

Table 3 provides a summary descriptive statistic of the input-output variables for the DEA-Malmquist model. The sample power purchase was approximately $550 \mathrm{GWh}$ with a standard deviation of about 1,956 GWh. The standard deviation of power purchase is almost three times the mean, suggesting statistically that there was disparity (Wilke, 2019) in the mean electricity purchases between ECG and NEDCO. On average, approximately $483 \mathrm{GWh}$ of electric power was purchased from 2000 to 2020 , with a standard deviation of about 14,356 GWh, indicating a widespread in the power sales distribution. The mean distribution losses were $26.1 \%$, with a standard deviation of $3.8 \%$. With this statistic, the mean (26.1\%) was greater than the standard deviation (3.8), suggesting not much variation in the losses as a percentage of the total electric power sold (distributed) to end-users. Frost and Sullivan (2015), as reported in (Adams et al., 2020), indicates that high electricity transmission losses, which is about 18\% in the sub-Saharan regions, accounts for low economic growth. It is important to add that reducing electricity transmission losses will yield not only economic benefits but also a reduction in grid-based greenhouse gas emissions, of which carbon dioxide has attained notoriety.

Table 2: Definitions, Measurement and Sources of Variable Data

\begin{tabular}{|c|c|c|c|}
\hline Variables & $\begin{array}{l}\text { Measurement } \\
\text { Definition }\end{array}$ & Type of Data & Data Source \\
\hline $\begin{array}{l}\text { Electricity } \\
\text { Power } \\
\text { Purchase }\end{array}$ & $\begin{array}{l}\text { Quantity of power } \\
\text { purchased from } \\
\text { the Volta River } \\
\text { Authority (VRA) } \\
\text { (in GWh) }\end{array}$ & Input & $\begin{array}{l}\text { Ghana Open Data Initiative } \\
\text { National Energy Statistics (2021) }\end{array}$ \\
\hline $\begin{array}{l}\text { Electricity } \\
\text { Power Sales }\end{array}$ & $\begin{array}{l}\text { Quantity of power sold } \\
\text { to end-users } \\
\text { (in GWh) }\end{array}$ & Output & $\begin{array}{l}\text { Ghana Open Data Initiative } \\
\text { National Energy Statistics (2021) }\end{array}$ \\
\hline$\%$ of Power Losses & $\begin{array}{l}\text { Inverse of } \\
\text { losses as } \\
\text { a percentage of } \\
\text { total power } \\
\text { transmitted (in \%) }\end{array}$ & Output & $\begin{array}{l}\text { Ghana Open Data Initiative } \\
\text { National Energy Statistics (2021) }\end{array}$ \\
\hline
\end{tabular}

\footnotetext{
${ }^{4}$ Since the passage of the Ghana Government Power Sector Reforms in 2005, the hitherto mandate of the Volta River Authority (VRA) as the promulgation of the Volta River Development Act, Act of the Republic of Ghana (1961) as a generation, transmission and distribution have been relinquished to independent and parastatals, namely: the Electricity of Ghana (ECG), the Northern Electricity Distribution Company (NEDCO) and Enclave Power Company (EPC). However, this study did not include EPC for lack of enough data points. The VRA's core mandate is electric power generation which the retail distribution utilities (ECG, NEDCO and EPC) purchase electric power.
} 
Table 3: Temporal changes of the Distribution Utilities Malmquist

Index and its components (2001-2020).

\begin{tabular}{llllll}
\hline \hline Year & EFFCH & TECHCH & PECH & SECH & TFPCH \\
\hline \hline $\mathbf{2 0 0 0 - 2 0 0 1}$ & 1,000 & 0.985 & 1,000 & 1 & 0.985 \\
$\mathbf{2 0 0 1 - 2 0 0 2}$ & 1,000 & 0.941 & 1,000 & 1 & 0.941 \\
$\mathbf{2 0 0 2 - 2 0 0 3}$ & 0.998 & 1,028 & 1,000 & 0.999 & 1,026 \\
$\mathbf{2 0 0 3 - 2 0 0 4}$ & 0.999 & 0.91 & 1,000 & 0.999 & 0.909 \\
$\mathbf{2 0 0 4 - 2 0 0 5}$ & 0.998 & 0.844 & 1,000 & 0.998 & 0.842 \\
$\mathbf{2 0 0 5 - 2 0 0 6}$ & 0.983 & 1,072 & 1,000 & 0.983 & 1,053 \\
$\mathbf{2 0 0 6 - 2 0 0 7}$ & 0.983 & 1,044 & 1,000 & 1,006 & 1.05 \\
$\mathbf{2 0 0 7 - 2 0 0 8}$ & 1,006 & 0.92 & 1,000 & 1,016 & 0.935 \\
$\mathbf{2 0 0 8 - 2 0 0 9}$ & 1,016 & 0.902 & 1,000 & 0.997 & 0.9 \\
$\mathbf{2 0 0 9 - 2 0 1 0}$ & 0.997 & 2,229 & 1,000 & 1,003 & 2,235 \\
$\mathbf{2 0 1 0 - 2 0 1 1}$ & 1,003 & 0.975 & 1,000 & 0.989 & 0.965 \\
$\mathbf{2 0 1 1 - 2 0 1 2}$ & 0.942 & 0.853 & 1,000 & 1,011 & 0.862 \\
$\mathbf{2 0 1 2 - 2 0 1 3}$ & 1,062 & 1,001 & 1,000 & 0.942 & 0.943 \\
$\mathbf{2 0 1 3 - 2 0 1 4}$ & 0.952 & 1,096 & 1,000 & 1,062 & 1,163 \\
$\mathbf{2 0 1 4 - 2 0 1 5}$ & 1,045 & 1,072 & 1,000 & 0.952 & 1,021 \\
$\mathbf{2 0 1 5 - 2 0 1 6}$ & 0.988 & 0.977 & 1,000 & 1,045 & 1,022 \\
$\mathbf{2 0 1 6 - 2 0 1 7}$ & 0.994 & 0.855 & 1,000 & 0.988 & 0.845 \\
$\mathbf{2 0 1 7 - 2 0 1 8}$ & 0.994 & 0.813 & 1,000 & 0.994 & 0.809 \\
$\mathbf{2 0 1 8 - 2 0 1 9}$ & 0.997 & 0.983 & 1,000 & 0.997 & 0.981 \\
$\mathbf{2 0 1 9 - 2 0 2 0}$ & 1,026 & 0.944 & 1,000 & 1,026 & 0.968 \\
\hline \hline Geometric & $\mathbf{1 , 0 0 0}$ & $\mathbf{0 . 9 9 7}$ & $\mathbf{1 , 0 0 0}$ & $\mathbf{1 , 0 0 0}$ & $\mathbf{0 . 9 9 7}$ \\
Mean & & & & & \\
\hline \hline & & & & &
\end{tabular}

Note: All Malmquist index averages are geometric means (Win4Deap 2).

Having modelled VRS output-orientated Malmquist productivity changes the index, the computed indices are described in line with literature the extant literature (Färe et al., 1998) as follows: an index of greater than unity shows productivity improvement in the sense that the electricity distribution utilities on average sold electricity power (in GWh) and minimized the losses as a percentage of the total power distributed in period $t+1$ relative to the total electricity purchased from the Volta River Authority. Stated differently, a representative power distributor (ECG or NEDCO) in the period $t+1$ is more efficient with reference to its own operations in the time period $t$.

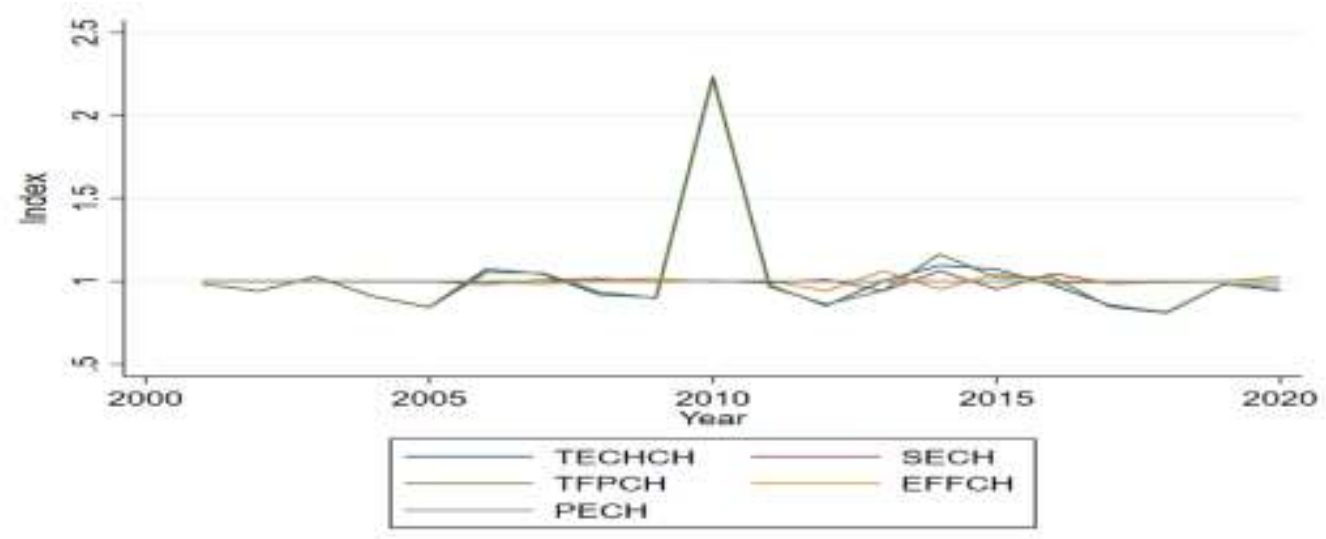

Figure 2: Trend of MPI Summary of Annual Means of ECG and NEDCo (2001-2020) 
Similarly, an index less than unity implies productivity regress, while and a unit index commensurate with constant productivity (i.e., no productivity improvement or deterioration), see (Andrea, Giulia, Chiara et al., 2018; Førsund, 2015; Masri \& Asbu, 2018) for similar interpretations in their recent works.

Table 3 and Figure 2 respectively show the DEA-MPI summary and the trend of annual means for the output-orientated model over 2000-2020 periods, where the TFPCH is decomposed into the SECH, TECHCH and EFFCH. Generally, the combination of Table 5 and Figure 2 suggest that the ECG and NEDCO experienced fluctuations in their total factor productivity performances. We observed that, at the mean point, TFP further marginally declined from 0.985 in 2001 to 0.968 , representing degrowth of about $0.017 \%$ using the full sample. In the last row of Table 3 (last column), we can observe that at the mean point, TFP declined marginally by about $0.3 \%$ over the period 2000-2020 for the Electricity Company of Ghana and the Northern Electricity Distribution Company. On average, the observed deterioration in the TFP was probably due to stagnation of the entities' managerial, scale and pure efficiency, coupled with a $0.3 \%$ degrowth in technological efficiency. In terms of the year-by-year PFP average performances, 2002-2003, 2005-2006, 2006-2007, 2009-2010, and 2014 to 2016 were the best registered years.

Table 4: Malmquist Productivity Index of Distribution Utility Means

\begin{tabular}{|c|c|c|c|c|c|c|}
\hline Utilities & & EFFCH & TECHCH & PECH & SECH & TFPCH \\
\hline Electricity Company of $\mathrm{G}$ & רa (ECG) & 1,000 & 0.947 & 1,000 & 1,000 & 0.947 \\
\hline Northern Electricity & Distribution & 1,000 & 1,049 & 1,000 & 1,000 & 1,049 \\
\hline \multicolumn{7}{|l|}{ Company (NEDCO) } \\
\hline Geometric Means & & 1,000 & 0.977 & 1,000 & 1,000 & 0.997 \\
\hline
\end{tabular}

For instance, 2014, 2015 and 2016 witnessed an average growth of 16.3\%, 2.1\% and 2.2\%, respectively, due to technological progress (innovations), efficiency improvement (catch-up), and the dynamics of growth in scale efficiency between 2015 and 2016. Interestingly, the sample average TFP performance between 2009 and 2010 was highly impressive, as there was about $123.5 \%$ growth in TFP. The observed impressive growth in TFP between 2009 and 2010 was due to TECHCH change of about $122.9 \%$ and $0.3 \%$ growth in scale efficiency. A further study incorporating structural break analysis can help shed light more on these results. Table 6 and Figure 3 provide a summary regarding the annual geometric mean values of the estimated DEA-MPI and decomposition for each of the electric power distribution utilities (named in the study as ECG and NEDCO).

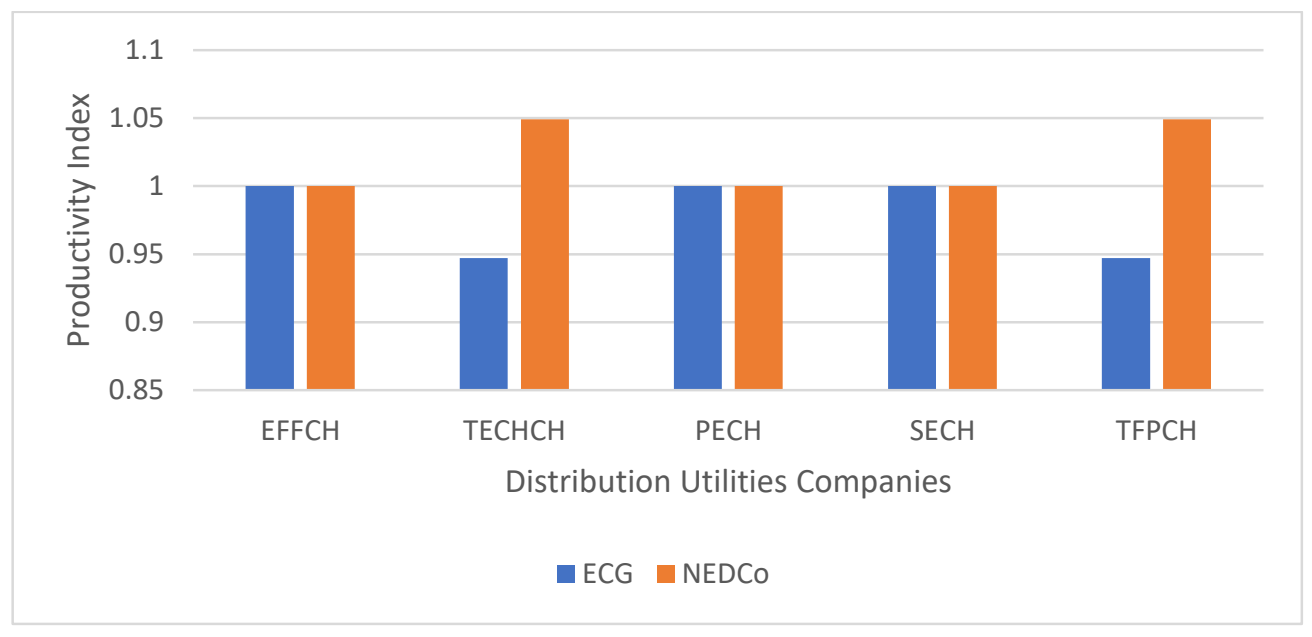

Figure 3: Productivity change and its components for ECG and NEDCo (geometric means)

We observed that both ECG and NEDCO recorded stagnation inefficiency, pure scale efficiency, and pure efficiency changes as their efficiency scores are unity. On the other hand, ECG recorded about a $5.3 \%$ decline in total factor productivity, mainly as a result of technical regression or lack of technical innovation. However, NEDCO reports a total factor productivity growth of about $4.9 \%$ for the study period. The $4.9 \%$ growth was mainly attributed to technological innovations. Probably, recent innovation interventions by NEDCO, such as the change of shield wire systems to 34.5 traditional kV feeder circuits and acquisition of smart meters aimed at improving supply reliability as well combating electricity theft within its operational jurisdiction, might have accounted for NEDCO's relative TFP improvement, given other factors. For the purpose of benchmarking under the DEA theory, for ECG to catch up, it should learn from the NEDCO as further research becomes available to confirm the findings in this study. 


\section{Conclusions}

This study used input and output panel data to empirically estimate total factor productivity (TFP) of the electricity distribution retail utilities, namely the Electricity Company of Ghana and Northern Electricity Distribution Company (NEDCO) in Ghana for the period 2000 to 2020. An output-orientated Data Envelopment Analysis (DEA) estimation technique was utilized to estimate the MPI (Malmquist total factor productivity indices) for the electricity distribution subsector of Ghana. The results show that the electricity power distribution utilities (ECG and NEDCO) posted total factor productivity growth rates fluctuations over the study sample. The average total factor productivity growth for the sample marginally declined at an annual rate of $0.3 \%$. These patterns are largely due to the dynamics of technological change (frontier shift) as compared to technical efficiency (catching up). At unit levels, the results show that the Electricity Company of Ghana registered relative stagnation in efficiency, pure efficiency and scale efficiency, with technological efficiency declining at an annual rate of 5.3\%, leading to degrowth in the company's total factor productivity performance. Similar to the Electricity Company of Ghana, the Northern Electricity Distribution also recorded empirically stagnation in efficiency, pure efficiency and scale efficiency in the study. However, the Northern Electricity Distribution Company gained a $4.9 \%$ growth in total factor productivity mainly due to technological innovation.

Based on the firm's annual productivity performance, it will be feasible for Electricity Company of Ghana to learn from technological innovations using the Northern Electricity Distribution Company Limited to improve its productivity, especially reducing electricity transmission losses. This is because; electricity transmission losses are proven to exert social, economic and environmental health costs on society. For example, grid infrastructure network systems and management that is less resilient and poor, leading to the high system and subsystems inefficiencies and highly technical transmission and distribution losses can lead to GHG emissions and pollution connected with grid power generation (Cheberyako, Varnalii, Borysenko et al., 2021; Energy technology and climate change: A call to action, 2000). In a nutshell, both the Electricity Company of Ghana and the Northern Electricity Distributed Company as distribution utilities of Ghana can improve their total productivity performance through managerial practices such as reduction in corruption and technological innovations to promote best practices. However, the integrity of these findings needs to be consistent as further study improves the current findings by employing DEA models that accommodate exogenous factors.

The study and its findings will be very relevant for future productivity and efficiency researchers and also energy economists who are more concerned about efficient utilization of energy and material resources, especially in the context of sustainable energy systems in low-come economies moving towards the 2030 Global Sustainable Development Agenda of the United Nations. Researchers who are interested in analyzing exogenous factor determinants of productivity index may expand on this study in order to derive the benefits of a nonparametric and parametric integrated approach to the subject matter in the present study.

Funding: The author wholly declared that this study was not funded by any external financial sources.

Conflicts of Interest: The authors declare no conflict of interest.

ORCID iD: https://orcid.org/0000-0001-5245-1063

\section{References}

[1] Abekah-Koomson, I. (2021). Total Factor Productivity Growth: Evidence from West African Economies. 22(6), $1405-1420$. doi:10.1177/0972150919856194

[2] Ackah, C. (2012). Tariffs and total factor productivity: The case of Ghanaian manufacturing firms.

[3] Adams, S. (2020). Electricity transmission, distribution losses and economic growth in South Africa. Heliyon, 6(11), e05564. doi:https://doi.org/10.1016/j.heliyon.2020.e05564

[4] Afriat, S. N. J. I. (1972). Efficiency estimation of production functions. 568-598.

[5] Aidoo, D. C. (2021). The effect of smallholder maize farmers' perceptions of climate change on their adaptation strategies: the case of two agro-ecological zones in Ghana. Heliyon, 7(11), e08307. doi:https://doi.org/10.1016/j.heliyon.2021.e08307

[6] Alfredsson, E. (2016). Internalizing external environmental effects in efficiency analysis: The Swedish pulp and paper industry $2000-2007$. Economic Analysis and Policy, 51, 22-31. doi:https://doi.org/10.1016/j.eap.2016.05.002

[7] Andrea, G. (2018). Measuring Efficiency in Hospitals. In A. Farazmand (Ed.), Global Encyclopedia of Public Administration, Public Policy, and Governance (pp. 1-5). Cham: Springer International Publishing.

[8] Angulo-Meza, L. (2019). A multiobjective DEA model to assess the eco-efficiency of agricultural practices within the CF + DEA method. Computers and Electronics in Agriculture, 161, 151-161. doi:https://doi.org/10.1016/j.compag.2018.05.037

[9] Arocena, P. (2020). Measuring and decomposing productivity change in the presence of mergers. European Journal of Operational Research, 282(1), 319-333. doi:https://doi.org/10.1016/j.ejor.2019.08.048

[10] Asamoah, L. A. (2019). Trade openness, FDI and economic growth in sub-Saharan Africa: do institutions matter? Transnational Corporations Review, 11(1), 65-79. doi:10.1080/19186444.2019.1578156

[11] Banker, R. D. (1984). Some Models for Estimating Technical and Scale Inefficiencies in Data Envelopment Analysis. 30(9), $1078-1092$. doi:10.1287/mnsc.30.9.1078

[12] Biggar, D. R., \& Hesamzadeh, M. R. (2014). The economics of electricity markets: John Wiley \& Sons.

[13] Bod'a, M., \& Považanová, M. (2020). Productivity patterns in Europe: adaptation of the Malmquist index to measuring group performance and productivity change over time. Empirica, 47(4), 949-989. doi:10.1007/s10663-019-09466-1 
[14] Carter, C. A. (2003). Agricultural productivity growth in China: farm level versus aggregate measurement. China Economic Review, 14(1), 5371. doi:https://doi.org/10.1016/S1043-951X(02)00086-X

[15] Charnes, A. (1985). Foundations of data envelopment analysis for Pareto-Koopmans efficient empirical production functions. Journal of Econometrics, 30(1), 91-107. doi:https://doi.org/10.1016/0304-4076(85)90133-2

[16] Charnes, A. (1978). Measuring the efficiency of decision-making units. European Journal of Operational Research, 2(6), $429-444$. doi:https://doi.org/10.1016/0377-2217(78)90138-8

[17] Cheberyako, O. (2021). "Green" finance as a modern tool for social and environmental security. Paper presented at the IOP Conference Series: Earth and Environmental Science.

[18] Chen, P.-C. (2015). The enhanced Russell-based directional distance measure with undesirable outputs: Numerical example considering CO2 emissions. Omega, 53, 30-40. doi:https://doi.org/10.1016/j.omega.2014.12.001

[19] Coelli, T. J., \& Rao, D. P. J. A. E. (2005). Total factor productivity growth in agriculture: a Malmquist index analysis of 93 countries, $1980-2000$. 32, 115-134.

[20] Coelli, T. J. (2005). An introduction to efficiency and productivity analysis: springer science \& business media.

[21] Cook, W. D. (2014). Data envelopment analysis: Prior to choosing a model. Omega, 44, 1-4. doi:https://doi.org/10.1016/j.omega.2013.09.004

[22] Cretì, A., \& Fontini, F. (2019). Electricity Transmission: Basic Principles. In A. Cretì \& F. Fontini (Eds.), Economics of Electricity: Markets, Competition and Rules (pp. 185-194). Cambridge: Cambridge University Press.

[23] Dar, A. H. (2021). The Efficiency of Indian Banks: A DEA, Malmquist and SFA Analysis with Bad Output. Journal of Quantitative Economics, 19(4), 653-701. doi:10.1007/s40953-021-00247-x

[24] [24] De Koeijer, T. J. (2002). Measuring agricultural sustainability in terms of efficiency: the case of Dutch sugar beet growers. Journal of Environmental Management, 66(1), 9-17. doi:https://doi.org/10.1006/jema.2002.0578

[25] Dzeha, G. C. O. (2018). Total factor productivity growth and human development: the role of remittances in Africa. 7(1), 47-72. Energy technology and climate change: A call to action (9264185631). (2000). Retrieved from

[26] Eyni, M. (2017). Applying inverse DEA and cone constraint to sensitivity analysis of DMUs with undesirable inputs and outputs. Journal of the Operational Research Society, 68(1), 34-40. doi:10.1057/s41274-016-0004-7

[27] Fan, S. J. A. J. o. (1991). Effects of technological change and institutional reform on production growth in Chinese agriculture. 73(2), $266-275$.

[28] Färe, R., \& Grosskopf, S. (2004). Modelling undesirable factors in efficiency evaluation: Comment. European Journal of Operational Research, 157(1), 242-245. doi:https://doi.org/10.1016/S0377-2217(03)00191-7

[29] Fare, R. (1993). Production Frontiers. Cambridge: Cambridge University Press.

[30] Fare, R. (1994). Production frontiers: Cambridge university press.

[31] Fare, R. (2015). Advances in data envelopment analysis (Vol. 8): World Scientific.

[32] Färe, R. (1998). Malmquist Productivity Indexes: A Survey of Theory and Practice. In R. Färe, S. Grosskopf, \& R. R. Russell (Eds.), Index Numbers: Essays in Honour of Sten Malmquist (pp. 127-190). Dordrecht: Springer Netherlands.

[33] Färe, R. (1997). Index numbers: essays in honour of Sten Malmquist: Springer Science \& Business Media.

[34] Farzipoor Saen, R. (2010). Developing a new data envelopment analysis methodology for supplier selection in the presence of both undesirable outputs and imprecise data. The International Journal of Advanced Manufacturing Technology, 51(9), $1243-1250$. doi:10.1007/s00170-010-2694-3

[35] Førsund, F. R. (2015). Dynamic Efficiency Measurement. In S. C. Ray, S. C. Kumbhakar, \& P. Dua (Eds.), Benchmarking for Performance Evaluation: A Production Frontier Approach (pp. 187-219). New Delhi: Springer India.

[36] Fukuyama, H., \& Weber, W. L. (2008). Japanese banking inefficiency and shadow pricing. Mathematical and Computer Modelling, 48(11), 1854-1867. doi:https://doi.org/10.1016/j.mcm.2008.03.004

[37] Gaggl, P. (2021). Does electricity drive structural transformation? Evidence from the United States. Labour Economics, 68, 101944. doi:https://doi.org/10.1016/j.labeco.2020.101944

[38] Garzarelli, G., \& Limam, Y. R. (2019). Physical capital, total factor productivity, and economic growth in sub-Saharan Africa. 2019, 22(1). doi:10.4102/sajems.v22i1.2309

[39] Glass, A. (2019). An Overview of Issues in Measuring the Performance of National Economies. In T. ten Raa \& W. H. Greene (Eds.), The Palgrave Handbook of Economic Performance Analysis (pp. 659-705). Cham: Springer International Publishing.

[40] Golany, B., \& Roll, Y. (1989). An application procedure for DEA. Omega, 17(3), 237-250. doi:https://doi.org/10.1016/0305-0483(89)90029-7

[41] Gomes, E. G., \& Lins, M. P. E. (2008). Modelling undesirable outputs with zero-sum gains data envelopment analysis models. Journal of the Operational Research Society, 59(5), 616-623. doi:10.1057/palgrave.jors.2602384

[42] Guo, X. (2021). International Comparison of the Efficiency of Agricultural Science, Technology, and Innovation: A Case Study of G20 Countries. 13(5), 2769.

[43] Gupta, S. (2021). Total factor productivity growth of sugarcane in Uttar Pradesh: parametric and nonparametric analysis. 10, $134-137$.

[44] Halkos, G., \& Petrou, K. N. (2019). Treating undesirable outputs in DEA: A critical review. Economic Analysis and Policy, 62, 97-104. doi:https://doi.org/10.1016/j.eap.2019.01.005

[45] Hirotaka, M. (2014). Effects of Research and Development Expenditure and Climate Variability on Agricultural Productivity Growth in Ghana. Journal of Disaster Research doi:10.20965/jdr.2014.p0443

[46] Hjalmarsson, L., \& Veiderpass, A. (1992). Productivity in Swedish Electricity Retail Distribution. The Scandinavian Journal of Economics, 94, S193-S205. doi:10.2307/3440259

[47] Hu, Z., \& Hu, Z. (2013). Introduction. In Electricity Economics: Production Functions with Electricity (pp. 1-25). Berlin, Heidelberg: Springer Berlin Heidelberg.

[48] Hua, Z., \& Bian, Y. (2007). DEA with Undesirable Factors. In J. Zhu \& W. D. Cook (Eds.), Modeling Data Irregularities and Structural Complexities in Data Envelopment Analysis (pp. 103-121). Boston, MA: Springer US. 
[49] Iliyasu, A. (2015). Productivity growth, technical change and efficiency change of the Malaysian cage fish farming: an application of Malmquist Productivity Index approach. Aquaculture International, 23(4), 1013-1024. doi:10.1007/s10499-014-9860-9

[50] Jiménez, R. (2014). Sizing electricity losses in transmission and distribution systems in Latin America and the Caribbean.

[51] Kao, C., \& Hwang, S.-N. (2021). Measuring the effects of undesirable outputs on the efficiency of production units. European Journal of Operational Research, 292(3), 996-1003. doi:https://doi.org/10.1016/j.ejor.2020.11.026

[52] Kataoka, M. (2020). Total factor productivity change in Indonesia's provincial economies for 1990-2015: Malmquist productivity index approach. Letters in Spatial and Resource Sciences, 13(3), 233-243. doi:10.1007/s12076-020-00256-z

[53] Koch, R. (2020). Green Public Procurement (GPP). In Green Public Procurement under WTO Law: Experience of the EU and Prospects for Switzerland (pp. 21-36). Cham: Springer International Publishing.

[54] Koopmans, T. (1951). Analysis of production as an efficient combination of activities. In Activity Analysis of Production and Allocation. New York: John Wiley and Sons.

[55] Kumbhakar, S. C., \& Lovell, C. K. (2003). Stochastic frontier analysis: Cambridge university press.

[56] Lee, B. L. (2017). Sources of airline productivity from carbon emissions: an analysis of operational performance under good and bad outputs. Journal of Productivity Analysis, 47(3), 223-246. doi:10.1007/s11123-016-0480-4

[57] Lin, J. Y. J. T. A. (1992). Rural reforms and agricultural growth in China. 34-51.

[58] Masri, M. D., \& Asbu, E. Z. (2018). Productivity change of national health systems in the WHO Eastern Mediterranean region: application of DEA-based Malmquist productivity index. Global Health Research and Policy, 3(1), 22. doi:10.1186/s41256-018-0077-8

[59] Matilde M and Eva B. (2020). Economic valuation of knowledge-based capital: An international comparison. In Measuring Economic Growth and Productivity: Foundations, KLEMS Models, and Extensions. CA: Elsevier.

[60] McMillan, J. (1989). The impact of China's economic reforms on agricultural productivity growth. 97(4), 781-807.

[61] Meniago, C., \& Lartey, E. K. K. (2021). Does FDI Affect Productivity and Growth in Sub-Saharan Africa? Journal of African Business, 22(2), 274292. doi:10.1080/15228916.2020.1745011

[62] Mombini, E. (2020). Global Malmquist index for measuring the economic productivity changes. 53(7-8), 1278-1285. doi:10.1177/0020294020923096

[63] Mydland, O., \& Lien, G. (2020). Application of Production Economics in the Electricity Distribution Sector. In S. C. Ray, R. G. Chambers, \& S. C. Kumbhakar (Eds.), Handbook of Production Economics (pp. 1-29). Singapore: Springer Singapore.

[64] Nagsarkar, T., \& Sukhija, M. (2014). Power system analysis (2nd ed.). New Delhi: Oxford University Press.

[65] National Energy Statistics. (2021). Retrieved from Accra: http://www.energycom.gov.gh/files/2021\%20published\%20Statistics.pdf

[66] National Energy Statistics (NES) Ghana. (2021). Retrieved from Ghana: http://www.energycom.gov.gh/files/2021\%20published\%20Energy\%20Statistics.pdf

[67] Orea, L. (2020). A Two-Level Top-Down Decomposition of Aggregate Productivity Growth: The Role of Infrastructure. In J. Aparicio, C. A. K. Lovell, J. T. Pastor, et al. (Eds.), Advances in Efficiency and Productivity II (pp. 173-191). Cham: Springer International Publishing.

[68] Oude Lansink, A., \& Bezlepkin, I. (2003). The effect of heating technologies on CO(2) and energy efficiency of Dutch greenhouse firms. J Environ Manage, 68(1), 73-82. doi:10.1016/s0301-4797(02)00233-5

[69] Park, S., \& Lee, C. (2012). Measuring Asia Airport Productivity Considering the Undesirable Output, Dordrecht.

[70] Pittman, R. W. (1981). The issue in Pollution Control: Interplant Cost Differences and Economies of Scale. Land Economics, 57(1), 1-17. doi: $10.2307 / 3145748$

[71] Prasetyo, A. D., \& Zuhdi, U. (2013). The Government Expenditure Efficiency towards the Human Development. Procedia Economics and Finance, 5, 615-622. doi:https://doi.org/10.1016/S2212-5671(13)00072-5

[72] Ragheb, M. (2017). Chapter 25 - Economics of Wind Power Generation. In T. M. Letcher (Ed.), Wind Energy Engineering (pp. 537-555): Academic Press.

[73] Rasmussen, S. (2013a). Economies of Scale and Size. In Production Economics: The Basic Theory of Production Optimisation (pp. 111-120). Berlin, Heidelberg: Springer Berlin Heidelberg.

[74] Rasmussen, S. (2013b). Introduction. In Production Economics: The Basic Theory of Production Optimisation (pp. 1-6). Berlin, Heidelberg: Springer Berlin Heidelberg.

[75] Rasmussen, S. (2013c). Productivity, Efficiency and Technological Changes. In Production Economics: The Basic Theory of Production Optimisation (pp. 59-68). Berlin, Heidelberg: Springer Berlin Heidelberg.

[76] Reinhard, S. (2000). Environmental efficiency with multiple environmentally detrimental variables; estimated with SFA and DEA. European Journal of Operational Research, 121(2), 287-303. doi:https://doi.org/10.1016/S0377-2217(99)00218-0

[77] Report on the Management of the Energy Sector Levies and Accounts. (2020). Retrieved from Accra, Ghana: https://mofep.gov.gh/sites/default/files/news/2020 ESLA Report v3.pdf

[78] Samuel, A. (2017). Electric Power Transmission, Distribution Losses, and Economic Growth in Ghana. In D. Ramesh Chandra (Ed.), Social, Health, and Environmental Infrastructures for Economic Growth (pp. 216-233). Hershey, PA, USA: IGI Global.

[79] Sequeira, T., \& Morão, H. (2020). Growth accounting and regressions: New approach and results. International Economics, 162, 67-79. doi:https://doi.org/10.1016/j.inteco.2020.01.003

[80] Seyedalizadeh Ganji, S. R., \& Rassafi, A. A. (2019). Measuring the road safety performance of Iranian provinces: a double-frontier DEA model and evidential reasoning approach. International Journal of Injury Control and Safety Promotion, 26(2), 156-169. doi:10.1080/17457300.2018.1535510

[81] Sharif, O. (2019). Productivity and efficiency analysis using DEA: Evidence from financial companies listed in Bursa Malaysia. Management Science Letters, 9(2), 301-312. doi:10.5267/j.msl.2018.11.010

[82] Shen, Y. (2020). Sustainable total factor productivity growth: The case of China. Journal of Cleaner Production, 256, 120727. doi:https://doi.org/10.1016/j.jclepro.2020.120727

[83] Solow, R. M. (1957). Technical change and the aggregate production function. 312-320. doi:https://doi.org/10.2307/1926047 
[84] Sueyoshi, T., \& Goto, M. (2011). DEA approach for unified efficiency measurement: Assessment of Japanese fossil fuel power generation. Energy Economics, 33(2), 292-303. doi:https://doi.org/10.1016/j.eneco.2010.07.008

[85] Sueyoshi, T., \& Goto, M. (2018). Environmental assessment on energy and sustainability by data envelopment analysis: John Wiley \& Sons.

[86] Sustainability Report. (2020). Retrieved from Accra: https://www.vra.com/media/2021/NRA\%20Sustainability\%20Report\%202020.pdf

[87] Thanassouli, E. (2001). Introduction to the Theory and Application of Data Envelopment AnalysisA Foundation Text with Software. New York: Springer Science + Business Media.

[88] Thijs ten, R. (2019). Performance: Output/Input Ration. In T. t. Raa \& W. H. Greene (Eds.), The Palgrave Handbook of Economic Performance Analysis: Palgrave Macmillan.

[89] Timmer, M. P., \& Ye, X. (2020). Chapter 18 - Accounting for growth and productivity in global value chains. In B. M. Fraumeni (Ed.), Measuring Economic Growth and Productivity (pp. 413-426): Academic Press.

[90] Undesirable Outputs Models. (2007). In Data Envelopment Analysis: A Comprehensive Text with Models, Applications, References and DEASolver Software (pp. 367-379). Boston, MA: Springer US.

[91] Wan, B., \& Zhou, E. (2021). Research of Total Factor Productivity and Agricultural Management Based on Malmquist-DEA Modeling. Mathematical Problems in Engineering, 2021, 2828061. doi:10.1155/2021/2828061

[92] Wang, C.-N. (2020). Eco-Efficiency Assessment for Some European Countries Using Slacks-Based Measure Data Envelopment Analysis. 10(5), 1760.

[93] Wilke, C. O. (2019). Fundamentals of data visualization: a primer on making informative and compelling figures: O'Reilly Media.

[94] Viet. (2019). Is data envelopment analysis a suitable tool for performance measurement and benchmarking in non-production contexts? Business Research, 12(2), 559-595. doi:10.1007/s40685-018-0077-z

[95] Wu, A., \& Ni, B. (2015). Line loss analysis and calculation of electric power systems: John Wiley \& Sons.

[96] Yang, H., \& Pollitt, M. (2009). Incorporating both undesirable outputs and uncontrollable variables into DEA: The performance of Chinese coal-fired power plants. European Journal of Operational Research, 197(3), 1095-1105. doi:https://doi.org/10.1016/j.ejor.2007.12.052

[97] Yu, M.-M. (2004). Measuring physical efficiency of domestic airports in Taiwan with undesirable outputs and environmental factors. Journal of Air Transport Management, 10(5), 295-303. doi:https://doi.org/10.1016/j.jairtraman.2004.04.001

[98] Zhao, P. (2022). China's transportation sector carbon dioxide emissions efficiency and its influencing factors are based on the EBM DEA model with undesirable outputs and spatial Durbin model. Energy, 238, 121934. doi:https://doi.org/10.1016/j.energy.2021.121934

[99] Zhou, P. (2012). Energy and CO2 emission performance in electricity generation: A non-radial directional distance function approach. European Journal of Operational Research, 221(3), 625-635. doi:https://doi.org/10.1016/j.ejor.2012.04.022

[100]Zhou, P. (2016). Data Envelopment Analysis for Measuring Environmental Performance. In S.-N. Hwang, H.-S. Lee, \& J. Zhu (Eds.), Handbook of Operations Analytics Using Data Envelopment Analysis (pp. 31-49). Boston, MA: Springer US.

[101]Zhu, J. (2014). Quantitative models for performance evaluation and benchmarking: data envelopment analysis with spreadsheets (Vol. 213): Springer 